\title{
The Seminars of Alain Badiou (1983-2016): General Preface
}

ALAIN BADIOU

\section{The Seminars in English}

It is a great pleasure for me to write this preface to the Englishlanguage edition of the entire collection of thirty years of my seminars. The information below is intended simply to shed some light on what these thirty years of public speaking have meant, to me and my various audiences, and why there may be some interest, or even pleasure, to be found in reading the seminars.

\section{A Few Historical Reference Points}

The word "seminar" should, in principle, refer to collective work around a particular problem. Instead, where these seminars are concerned, it refers to my own individual, albeit public, work on many different problems, all of which were nonetheless united by a philosophical apparatus explicitly claiming to be systematic.

Admittedly, the word "seminar" was already used in the latter sense with reference to Lacan's famous seminar, which, for me and many other people, has raised the bar very high when it comes to this sort of thing.

That a large part of my teaching took the form of such a seminarwhose ongoing publication in French, and now in English and 
Spanish, will show that it remained virtually free from any institutional authority-was originally due to pure chance.

At the beginning of the academic year 1966-67, while I was the senior class teacher at the boys' high school in Reims, I was appointed lecturer in an establishment that had just been created and that testified to the rapid expansion of higher education in the supremely Gaullist France of those years: the College universitaire de Reims, affiliated with the University of Nancy. Initially, only socalled propaedeutic [i.e., college preparatory] teaching was to be provided there (at the time, there was a first year of studies with that name, validated by a final exam that, if successfully passed, allowed students to begin their first year of university). So I was asked to teach the philosophy option in this preparatory year. But all of a sudden, thanks to one of those nasty betrayals so typical of academic life, the University of Nancy announced that, for the time being, it couldn't relinquish its philosophical powers to Reims and that there wouldn't be any philosophy option for the preparatory program to which my position was attached.

So there I was, a teacher of a nonexistent discipline. Given these circumstances, what else was there to do but hold an open seminar? And that's what I did for two years (1966-67 and 1967-68), before-I have to brag a bit here-an increasingly large audience and, what was even more flattering to me, one that was there out of pure interest since there was no final exam to reward their faithful attendance.

If I'd had the energy to look for my notes from that time long ago (when no one had either the idea or the means to bring in one of those big, clunky tape recorders to record my improvisations) and to revise those notes and turn them into a written text, I could have proudly begun this edition of the seminars with the one from 1966-67-fifty years of free speech!-, the year devoted to Schopenhauer, and then continued with the 1967-68 seminar, when my 
syllabus was focused on Mallarmé, Rimbaud, and Lautréamont, in that order. The Chants de Maldoror, however, which I had intended to begin dealing with in early May, was sacrificed on the altar of the mass movement.

And then, as a result of that May upheaval, which was to drastically change my life and my thinking about many issues other than academic appointments, I was appointed (since those appointments continued to be made nonetheless) Assistant Professor at the Experimental University of Vincennes, which soon became Paris 8.

The context in which I began teaching courses there was so feverish and politically so intense, the actions afoot there so radical, that the government decided that the philosophy degrees granted by Paris 8 would have no national accreditation! So there I was again, forced to give an open seminar since there was no state validation of our teaching efforts, despite the fact that they were highly innovative, to say the least.

This marginalization lasted for years. So-if, once again, the documentation really allowed for it-I could give an account of the free and open seminars of the $1970 \mathrm{os}$, which, when all the exciting, frenetic collective action going on at the time allowed them to take place, were devoted in particular to the Hegelian dialectic, to Mallarmé again, to my beloved Plato, and to Lacan, always before audiences that were there out of pure interest alone, since there was no exam and therefore no academic credit to validate their attendance.

Actually, a synthetic account of that period does exist: my book Theory of the Subject, published by Seuil in 1982 under the editorship of François Wahl (English translation published by Continuum, 2009). It provides an admittedly very freely rewritten account of the seminars that were held between January 1975 and June 1979.

Beginning in those years, as a result of the so-called political normalization, things calmed down in the universities, even in the one 
in Vincennes, which had incidentally been moved to Saint-Denis. In the early 1980s, the government authorities decided that we of the glorious Department of Philosophy-where you could hear lectures by Michel Foucault, Michel Serres, François Châtelet, Gilles Deleuze, Jean-François Lyotard, and Jacques Rancière-deserved to have the national accreditation we'd lost gradually restored. It was from that time on, too, that the seminars began to be systematically recorded by several different attendees. Little wonder, then, that I decided to publish all of the seminars between 1983 and the present: for these thirty-odd years, abundant, continuous documentation exists.

Not that the locations, the institutions, and the frequency didn't change. Indeed, starting in 1987 the seminar moved to the College international de philosophie, which owed its creation in large part to the determined efforts of everyone in "living [i.e. non-traditional] philosophy" who felt put down and badmouthed by the University, Lyotard and Derrida being the two most emblematic names at the time. In that setting, I rediscovered the innocence of teaching without exams or validation: the seminar was now officially open and free of charge to everyone (for the reasons I mentioned above, it had actually always been so). It was held in the locales that the College secured or bargained hard to secure for its activities: the old École polytechnique on the rue Descartes, the École normale supérieure on the boulevard Jourdan, an industrial institution on the rue de Varenne, the Institut catholique on the rue d'Assas, and the main auditorium of the University of Paris 7 at Jussieu.

In 1998, when my seminar had been held under the auspices of the College international de philosophie for ten years, a crisis of sorts erupted: one faction of the College's administration viewed with suspicion both the form and the content of what I was doing. As far as the form was concerned, my status in the College was an exceptional one since, although I'd initially been properly inducted 
into it under Philippe Lacoue-Labarthe's presidency, I had never been officially re-elected as a member of the College. The content was viewed with suspicion because in those times dominated by the antitotalitarian ideology of human rights, rumors were going around that my teaching was "fascist." As I was unwilling to put up with such an atmosphere, I broke off my seminar midyear, thereby causing a lot of confusion.

I set it up the following fall at the École normale supérieure, where I'd been appointed professor. It remained there for fifteen years, which is pretty good, after all.

But this seminar was fated to always end up antagonizing institutions. I had to use the largest lecture halls at the ENS due to the sizeable audiences the seminar attracted, but at the start of the 2014 school year there was a dark plot afoot to deny me all access to those rooms and recommend that I accommodate around 250 people in a room that held only 80 ! After driving Lacan out, the prestigious ENS drove me out too! But, after all, I told myself, to suffer the same fate as Lacan was in its own way a glorious destiny. What happened to me next, however, can literally be called a "coup de théâtre," a dramatic turn of events. My friend Marie-José Malis, the outstanding theater artist and great renovator of the art of directing, was appointed artistic director of the Théâtre de la Commune in the Paris suburb of Aubervilliers. She offered to let me hold my seminar there, and I enthusiastically accepted. For two and a half years, in the heart of a working-class suburb, I stood on the stage before a full house and interspersed my final seminars, which were connected with the writing of my last "big" book, L'Immanence des vérités, with actual theatrical presentations. I was generously assisted in this by Didier Galas, who created the role of Ahmed in my four-play cycle, written in the 1980 and 1990 for the artistic and stage director Christian Schiaretti: Ahmed the Subtle, Ahmed Gets Angry, Ahmed the Philosopher, and The Pumpkins. On January 16, 2017, my Final Seminar 
took place in the Théâtre de la Commune in Aubervilliers, where pure philosophy, congratulatory messages, anecdotes, and theatrical productions all combined to celebrate the seminar's long history for one last time.

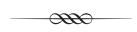

I'd always wanted the seminar to be for people who worked. That's why, for a very long time, it took place between 8 and 1o PM, on Tuesdays for a few years, on Wednesdays for probably twenty years, if not more, and on Mondays between 2014 and the time it ended in 2017, because theaters are dark on Mondays ...

In these various places, there was a first period-five years, from 1987 to $1992-$ when the seminar had a feeling of spontaneity to it as it ran through philosophy's "conditions," as they're called in my doctrine: poetry, the history of philosophy (the first seminar on Plato's Republic dates back to 1989-9o), politics, and love. It was over the course of those years, especially during the sessions on the rue de Varenne, that the size of the audience increased dramatically.

From 1992 on, I began putting together large conceptual or historical ensembles, which I treated over several consecutive years: anti-philosophy, between 1992 and 1996; the Subject, between 1996 and 1998; the twentieth century, between 1998 and 2001; images of the present time, between 2001 and 2004; the question of subjective orientation, in thought and in life, from 2004 to 2007. I dealt with Plato, from 2007 to 2010; then with the phrase "changing the world," from 2010 to 2012. The final seminar, which was held, as I mentioned above, in a theater, was entitled "The Immanence of Truths."

I should point out that, although it was a more or less weekly seminar at the beginning, it was a monthly one for all of the final years of its existence. 


\section{The Seminar's Form}

As I mentioned at the outset, my seminar ultimately took the form of an ex cathedra lesson, the venerable old form known as the "formal lecture" [cours magistrall. But this was the outcome of a long evolution. Between 1969 and, let's say, the late 1980s, there were questions from the audience. It was obviously a lot easier to entertain questions in a room with 40 people at Vincennes than in a theater with 3oo. But it was also a matter of the time period. Initially at Vincennes, every "class" was a sort of steeplechase in which the hedges, which had to be jumped over elegantly and efficiently, were the constant hail of questions. It was there, as well as in the tumultuous political meetings I attended, that I learned how to stay unfailingly focused on my own thinking while agreeing with perfect equanimity to answer any question calmly, even if it was clearly a side issue. Like Claudel's God, I took crooked paths to reach my goal.

I must admit that, little by little, with the "normalization," I was able to rely on the audience's increasing unwillingness to listen to overly subjective rambling, rants with no connection to the subject under discussion, biased ideological assaults, complaints about not understanding or boasts about already knowing it all. Ultimately, it was the dictatorship of the masses that silenced the frenzied dialectic of interruptions without my having to change, on my own, my relationship with the audience. In the Jules Ferry auditorium at the ENS or in the Théâtre de la Commune, nobody interrupted anymore, or even, I believe, considered doing so, not out of fear of a stern refusal on my part but because the ambient opinion was no longer in favor of it.

I never ruled out having someone else come and speak, and thus, over time, I extended invitations to a number of people: François Regnault, to speak on theater; Jean-Claude Milner, to speak on 
Lacan; Monique Canto, to speak on Plato; Slavoj Žižek, to speak on orientation in life, etc. These examples give you a sense of my eclecticism.

But in the final analysis, the seminar's form, solidly in place for about twenty-five years, remained by and large that of a one-man show. Session by session, I began with careful preparation, resulting in a set of lecture notes-I never really wrote out a seminar-that provided the basic outline, a few summary sentences, and the quotations or references used. Often, I gave out a handout containing the texts that I would read and comment on. I did this because my material was nothing like philosophical references in the traditional sense of the term. In particular, I had frequent recourse to the intellectual concentration that poetry allows for. Naturally, I also engaged in logico-mathematical formalism. However, it's very difficult to make extensive use of that resource before large audiences. I usually reserved it for another seminar, one that could be called arcane, which I held for a long time on Saturday afternoons and which contributed directly to my densest_-and philosophically most important-books: Being and Event and Logics of Worlds. But for the time being there are no plans to publish these "other" seminars.

\section{What Purpose Did the Seminar Serve?}

It's hard for me to say in what respect my seminar was useful for people other than myself. What I noticed, however, was that its transmission of sometimes very complex subjects was of a different sort from that of my writings on these same subjects. Should it be said that the seminar was easier? That's not exactly the point. Clearly, philosophy has always combined oral activity and writing and has often privileged the oral over the written, as did its legendary founder, namely, Socrates. Even those-like Derrida-who promoted the primacy of writing were very careful never to overlook physical presence and 
the opportunities oral presentation provides for transference love, which Plato already theorized in his Symposium.

But I think that the oral presentation, as far as I myself and no doubt many attendees were concerned, conveyed the movement of thought, the trajectory of the investigation, the surprise of discovery, without having to subject them to the pre-established discipline of exposition, which is largely necessary whenever you write. It had the musical power of improvisation, since my seminar was not in fact written out. I met many seminar attendees who hadn't read my books. I could hardly commend them for it, obviously. But I understood that the thinking-on-the-spot effect of the oral presentation had become the most important thing to them. Because if the seminar "worked" as it should—which was naturally not guaranteed-the audience felt almost as if they themselves had thought up what I was talking to them about. It was as though all I'd done, in Platonic parlance, was trigger a recollection in them, whereas philosophical writing per se demanded sustained and sometimes unrewarding effort. In this respect, the seminar was certainly easy, but such easiness also left traces, often unconscious ones, of which attendees who thought they'd understood everything would have been wise to be wary.

For me, there's no question that the seminar served as a laboratory. I tested out ideas in it, either already established ones or even ones that emerged during my public improvisations, by presenting them from a variety of perspectives and seeing what happened when they came in contact with texts, other ideas, or even examples from contemporary situations in politics, art and public opinion. One of the great advantages of oral presentation is to be able to repeat without really boring your audience-which would be very difficult to do in writing-because intonation, movements, gestures, slight accentuations, and changes in tone give repetition enough charm to make it not just acceptable but even retroactively necessary. So the seminar went hand in hand with the inner construction of my thought, 
something Deleuze would have called the moment of invention of the concept, and it was like a partly anarchic process whose energy could later be captured by prose in order to discipline it and incorporate it into the philosophical system I've created, whose final, and I daresay eternal, form, is nonetheless the written form.

Thus, some of the seminars directly became books, sometimes almost immediately, sometimes later. For example, Saint Paul: The Foundation of Universalism (the 1995-96 seminar, published by Presses Universitaires de France in 1997; English translation published by Stanford University Press in 2006); Wittgenstein's Antiphilosophy (the 1993-94 seminar, published by Nous in 2009; English translation published by Verso in 2011); The Century (the 1998-2001 seminar, published by Seuil in 2005; English translation published by Polity in 2007). In all three of these cases, the content of the books is too similar to that of the seminars for there to be any need for the latter to be published for the foreseeable future.

But all the seminars are in a dialectic with books, sometimes because they exploit their effects, sometimes because they anticipate their writing. I often told my seminar attendees that I was without a doubt throwing myself on the mercy of their attention span (a two-hour seminar before such an audience is truly a performance), but that their presence, their degree of concentration, the need to really address my remarks to them, their immediate reaction to my improvisations-all of that was profoundly useful to my system-building efforts.

The complete set of volumes of the seminar may, in the long term, be the true heart of my work, in a dialectical relationship between the oral and the written. Only the readers of that complete set will be able to say. It's up to you now, dear reader, to whom every philosopher addresses himself or herself, to decide and pronounce your verdict. 